\title{
Begonia bimaensis, a new species of Begonia from Sumbawa Island, Indonesia
}

\author{
N.K.E. Undaharta ${ }^{1}$ I Made Ardaka, Agung Kurniawan \& Bayu Adjie \\ Bali Botanic Garden - Indonesian Institute of Sciences \\ Candikuning, Baturiti, Tabanan 82191, Indonesia \\ 'nika002@lipi.go.id
}

\begin{abstract}
A new species of Begonia sect. Reichenheimea, B. bimaensis Undaharta \& Ardaka, is described from Mt Muria in Bima District, Sumbawa Island, Indonesia. The species is a narrow endemic, currently known from only one population, and has been assessed as Vulnerable using IUCN criteria.
\end{abstract}

Keywords. Begonia, Sumbawa, new species

\section{Introduction}

The pantropical genus Begonia L. is one of the largest genera of flowering plants, comprising more than 1700 species (Hughes, 2008 and the many species described since then). Southeast Asia is a hotspot of species diversity for Begonia (Hughes, 2008), with Indonesia being particularly rich in species and with many species still being discovered (Hughes, 2008; Thomas \& Hughes, 2008; Girmansyah, 2009, 2012; Girmansyah et al., 2009; Hughes et al., 2009; Thomas et al., 2009, 2011; Ardi \& Hughes, 2010; Wiriadinata, 2011; Ardi et al., 2013, 2014; Ardi, 2014; Lin \& Peng, 2014). From these works the current estimate for the total number of Begonia species in Indonesia is 213 species.

There are only a few Begonia species recorded for Nusa Tenggara Barat (West Nusa Tenggara), and currently only two species have been reliably recorded from the largest island, Sumbawa (B. multangula Blume - Hughes \& Pullan, 2007; and B. muricata Blume - Hughes, 2008). Examination of herbarium specimens shows that several endemic species remain to be described from the region. The lack of records for widely distributed species, such as Begonia longifolia Blume, may also reflect the poor documentation of the Begonia flora of Sumbawa, since we have seen herbarium material of this species from the surrounding islands of Bali, Lombok, Sumba and Timor.

During a fieldtrip to Sumbawa Island, a small population of an unknown Begonia from Mount Maria was found. Two living specimens were brought to the Bali Botanic Garden where they were cultivated. As these specimens could not be identified, the new species Begonia bimaensis is described here. Begonia bimaensis is placed in Begonia section Reichenheimia (Klotzsch) A.DC. as it exhibits the characters typical of the section: rhizomatous or tuberous stems, protandrous inflorescences, and three locular ovaries with entire placentae (Doorenbos et al., 1998). 
All available Begonia specimens from the Herbarium of Bali Botanic Garden, $\mathrm{BO}, \mathrm{E}, \mathrm{K}, \mathrm{L}$ and SING have been consulted and hence it must be assumed, at least until more intensive collecting in Sumbawa reveals otherwise, that the species described here has a very restricted range.

\section{Species description}

\section{Begonia bimaensis Undaharta \& Ardaka sp. nov. § Reichenheimia}

Similar to Begonia sendangensis Ardi but differs in the dense white, long hairs on the adaxial surface of leaves (versus glabrous), female flower with four tepals (versus three) and the ovary with 3 wings, reddish, equal or subequal, locules 3 , placentation axillary. Ovary characters for Begonia sendangensis, pinkish, equal, rounded at base, placentae axile. - TYPE: Cultivated at Bali Botanical Garden from vegetative material collected in the wild from Indonesia, West Nusa Tenggara, Sumbawa Island, Bima, Wawo, Ntori, Mt. Maria, 08 $29^{\prime} 55^{\prime \prime S} 118^{\circ} 52^{\prime} 41^{\prime \prime} \mathrm{E}, 525 \mathrm{~m}$ elev., 4 October 2010. Cultivated material vouchered and selected as type material on 11 December 2012 under I Made Suja HK 1276 (holotype Herbarium Bali Botanic Garden; isotype BO). (Fig 1)

Perennial, tuberous, monoecious small herb, less than $10 \mathrm{~cm}$ tall. Stems very reduced, an elongated tuber $1.5-1.8 \mathrm{~cm}$ long, diameter $3-4 \mathrm{~mm}$, internodes c. $1 \mathrm{~mm}$ long; stipules ovate to elliptic, c. $3 \times 1-2 \mathrm{~mm}$, pale green, apex projecting up to c. $6 \mathrm{~mm}$ long, persistent. Leaves alternate; petioles $3.5-7.5 \mathrm{~cm}$ long, red, sparsely covered with long pilose hairs c. 2-5 mm long; lamina basifixed, 4-6.5 $\times 2.5-5 \mathrm{~cm}$, ovate to broadly ovate, asymmetric, base cordate, lobes not or rarely overlapping, apex acuminate, margin shallowly to moderately lobed, ciliate with a fringe of hairs; adaxial surface green to reddish green, densely covered with white pilose hairs, abaxial surface red, glabrous; venation palmate, red, primary veins $5-6$, adaxially green to brownish, abaxially pale red. Inflorescence a simple dichasial cyme, few-flowered, axillary, protandrous, bisexual; peduncle 3-6 cm long, pink, glabrous; bracts minute, sub-orbicular, margin slightly fimbriate, deciduous. Male flowers: pedicels 15-18 mm long; tepals 4, pink, glabrous, two outer tepals ovate to suborbicular, 8-14 $\times 8-11 \mathrm{~mm}$, apex rounded, two inner tepals narrowly obovate, 5-12 × 4-6 $\mathrm{mm}$, tip slightly obtuse, androecium yellow, symmetric, globose; stamens c. 40, filaments fused at base into short column c. $1 \mathrm{~mm}$ long, anthers c. $0.5 \mathrm{~mm}$ long, obovate, dehiscing through lateral slits more than half the length of the anther, apex slightly retuse. Female flowers: pedicels $2.5-4 \mathrm{~mm}$ long, bracteoles present, with hairs, ovate, c. $2 \mathrm{~mm}$ long, persistent; tepals 4, pink, glabrous, two outer tepals suborbicular, c. $9.5-12 \times 7.5-12.5 \mathrm{~mm}$; glabrous, two inner tepals elliptic, c. 8-10 × 3.5-5 mm; ovary 3-4 ×4 mm (excluding wings), ellipsoid, glabrous, greenish white, locules 3 , placentation axile, wings 3 , equal or sub equal, reddish green triangular, widest point at the middle of the ovary, c. $1.5 \mathrm{~mm}$ long; stigma 3, U-shaped, stigmatic surface twisted. Fruit: pedicel 2-5 mm long, capsule ovoid, 4-5 $\times 5-6.5 \mathrm{~mm}$ (excluding wings), dehiscent, splitting along the wing attachments, wing shape as for 


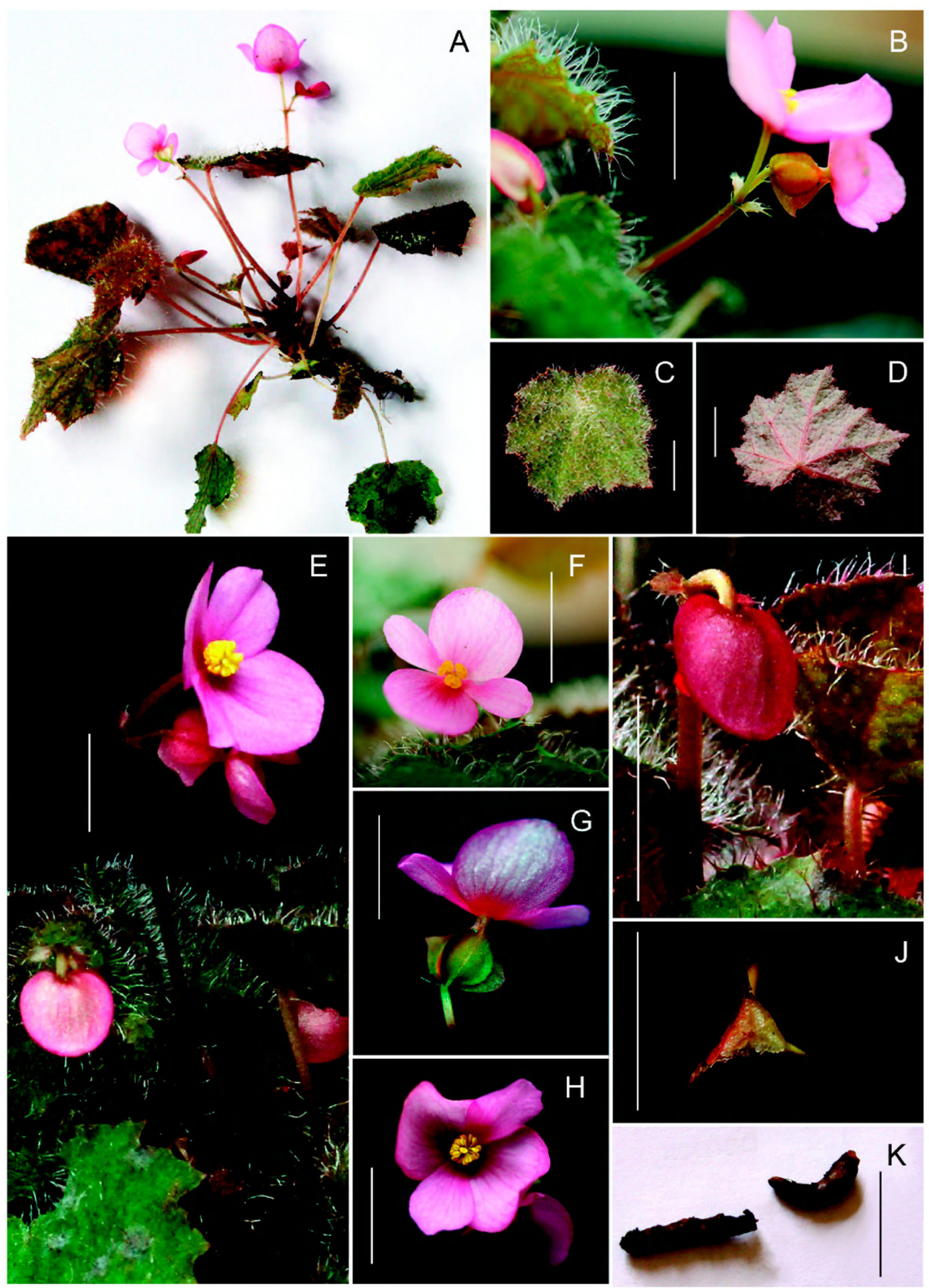

Fig. 1. Begonia bimaensis from cultivated material in Bali Botanic Garden. A-B. Habit; C. Leaf, adaxial surface; D. Leaf, abaxial surface; E. Inflorescence; F. Female flower; G. Female flower; H. Male flower; I. Bracts; J. Ovary transverse section; K. Tubers; Scale bars: $1 \mathrm{~cm}$. (Photos: Gede Wawan Setiadi) 
the ovary, wings widest subapically, $8 \mathrm{~mm}$. Seeds numerous, brown, widely ellipsoid or ellipsoid, c. $0.35 \mathrm{~mm}$ long, 0.2 wide.

Distribution. Endemic to Mt Muria, Bima district, Sumbawa, West Nusa Tenggara, Indonesia.

Habitat. This species grows on steep rocky cliffs in shade, at c. $525 \mathrm{~m}$ altitude.

Preliminary IUCN conservation assessment. Begonia bimaensis is probably a narrowly endemic species, restricted to Mt Muria which is not formally protected. As the species is known only from a single population with a small number of individuals, a provisonal IUCN category of CR D is appropriate (IUCN, 2012).

Notes. The epithet 'bimaensis' refers to the Bima district from where the type material was collected. Begonia bimaensis is unusual in Begonia section Reichenheimia in Indonesia on account of its tuberous habit, which is similar to Begonia sendangensis, a species recently described from the neighbouring island of Lombok (Ardi et. al, 2014). However, apart from the presence of tubers, the two species are morphologically dissimilar and Begonia bimaensis can easily be distinguished by the dense white long hairs on the upper surface of the leaves. The number of tepals in the female flower and the shape of the ovary wings provide further differences: The female flowers of Begonia bimaensis have four tepals whereas the female flowers of $B$. sendangensis have three tepals; in B. bimaensis, the shape of the wings in the ovary is very distinctive, being triangular and mostly cuneate at apex (versus rounded at base and truncate at the apex), reddish.

ACKNOWLEDGEMENTS. The authors would like to express their gratitude to Nyoman Sudiatna for collecting the living specimen (during a fieldtrip supported by the Research Incentive for Researchers and Engineers No. $053 / \mathrm{m} / \mathrm{Kp} / \mathrm{II} / 2010$ to $\mathrm{AK}$ ), and to the curators of the Herbarium of Bali Botanic Garden, BO, E, K, L and SING for allowing us access to herbarium material. We also thank Mark Hughes (Royal Botanic Garden Edinburgh) for editing and correcting the English and Wisnu Ardi (Bogor Botanic Gardens) for his assistance.

\section{References}

Ardi, W.H. (2014). Two new species of Begonia (Begoniaceae) from Sulawesi, Indonesia. Edinburgh J. Bot. 71: 259-268.

Ardi, W.H. \& Hughes, M. (2010). Begonia droopiae Ardi (Begoniaceae). A new species of Begonia from West Sumatra. Gard. Bull. Singapore 62: 17-22.

Ardi, W.H., Ardhaka, I.M., Hughes, M., Undaharta, N.K.E., Girmansyah, D. \& Hidayat, S. (2013). Two new species of Begonia (Begoniaceae) from Bali and Lombok. Gard. Bull. Singapore 65: 135-142. 
Ardi, W.H., Kusuma, Y.W.C., Lewis, C.E., Risna, R.R., Wiriadinata, H., Abdo, M.E. \& Thomas, D.C. (2014). Studies on Begonia (Begoniaceae) of the Molucca Islands I: Two new species from Halmahera, Indonesia, and updated description of Begonia holosericea. Reinwardtia 14: 19-26.

Lin, C.-W. \& Peng, C.-I. (2014). Begonia natunaensis (Sect. Reichenheimia, Begoniaceae), a new species from Natuna Island, Indonesia. Taiwania 59: 368-373.

Doorenbos, J., Sosef, M.S.M. \& de Wilde, J.J.F.E. (1998). The sections of Begonia including descriptions, keys and species lists (Studies in Begoniaceae VI). Agric. Univ. Wageningen Pap. 98: 1-266.

Girmansyah, D. (2009). A taxonomic study of Bali and Lombok Begonia (Begoniaceae). Reinwardtia 12: 419-434.

Girmansyah, D. (2012). Begonia ranaiensis (Begoniaceae), a new species from Mt Ranai, Natuna Island, Indonesia. Kew Bull. 68: 1-4.

Girmansyah, D., Wiriadinata, H. \& Thomas, D.C. (2009). Two new species and one new subspecies of Begonia (Begoniaceae) from Southeast Sulawesi, Sulawesi, Indonesia. Reinwardtia 13: 69-74.

Hughes, M. (2008). An Annotated Checklist of Southeast Asian Begonia. Edinburgh: Royal Botanic Garden Edinburgh.

Hughes, M. \& Pullan, M. (2007). Southeast Asian Begonia Database. Royal Botanic Garden Edinburgh. http://elmer.rbge.org.uk/Begonia/ (accessed on 18 Aug. 2014).

Hughes, M., Girmansyah, D., Ardi, W.H. \& Nurainas (2009). Seven new species of Begonia from Sumatra. Gard. Bull. Singapore 61: 29-44.

IUCN (2012). IUCNRed List Categories and Criteria: Version 3.1. Second Edition. Switzerland, Gland and UK, Cambridge: IUCN.

Thomas, D.C. \& Hughes, M. (2008). Begonia varipeltata (Begoniaceae): A new peltate species from Sulawesi, Indonesia. Edinburgh J. Bot. 65: 369-374.

Thomas, D.C., Ardi, W.H. \& Hughes, M. (2011). Nine new species of Begonia (Begoniaceae) from South and West Sulawesi, Indonesia. Edinburgh J. Bot. 68: 225-255.

Thomas, D.C, Ardi, W.H., Hartutiningsih \& Hughes, M. (2009). Two new species of Begonia (Begoniaceae) from South Sulawesi, Indonesia. Edinburgh J. Bot. 66: 229-238.

Wiriadinata, H. (2011). A new species of Begonia (Begoniaceae) from Sagea Lagoon, Weda Bay, Halmahera Island, North Moluccas Indonesia. Reinwardtia 13: 263-270. 


\section{$2 \mathrm{BHL}$ Biodiversity Heritage Library}

Undaharta, Ni Kadek Erosi et al. 2015. "Begonia bimaensis, a new species of Begonia from Sumbawa Island, Indonesia." The Gardens' bulletin, Singapore 67(1), 95-99. https://doi.org/10.3850/s2382581215000101.

View This Item Online: https://www.biodiversitylibrary.org/item/223283

DOI: https://doi.org/10.3850/s2382581215000101

Permalink: https://www.biodiversitylibrary.org/partpdf/229508

\section{Holding Institution}

Singapore Botanic Gardens, National Parks Board Singapore

\section{Copyright \& Reuse}

Copyright Status: In copyright. Digitized with the permission of the rights holder.

License: http://creativecommons.org/licenses/by-nc-sa/4.0/

Rights: https://biodiversitylibrary.org/permissions

This document was created from content at the Biodiversity Heritage Library, the world's largest open access digital library for biodiversity literature and archives. Visit BHL at https://www.biodiversitylibrary.org. 